\title{
Leucine-Zipper-Like Transcriptional Regulator 1
}

National Cancer Institute

\section{Source}

National Cancer Institute. Leucine-Zipper-Like Transcriptional Regulator 1. NCI

Thesaurus. Code C128259.

Leucine-zipper-like transcriptional regulator 1 ( $840 \mathrm{aa}, \sim 95 \mathrm{kDa}$ ) is encoded by the human LZTR1 gene. This protein may be involved in embryogenesis. 